\title{
Effect of tyrosine ingestion on cognitive function and load carriage performance in the heat
}

\author{
Nicole Coull, Josh Foster, Bryna Chrismas, Lee Taylor ${ }^{*}$ \\ From 15th International Conference on Environmental Ergonomics (ICEE XV) \\ Portsmouth, UK. 28 June - 3 July 2015
}

\begin{abstract}
Introduction
Prolonged exercise-heat-stress impairs both exercise performance and cognitive function. Military based operations are often performed in hot environmental conditions and thus performance and safety may be compromised which could be potentially life threatening. Ingestion of tyrosine (TYR), a catecholamine precursor has been shown to improve exercise performance [1] and cognitive function [2] in hot environments, but no study has assessed the effects of TYR in a simulated military setting in the heat simultaneously assessing steady sate exercise performance, time-trial performance and alterations in various facets of cognitive function. Therefore, the aim of this study was to investigate the effect of $150 \mathrm{mg} . \mathrm{kg}$ TYR on steady state exercise, cognitive function and time-trial performance in the heat.
\end{abstract}

\section{Methods}

Eight recreationally active, healthy males [age 23(1) y, height $176.4(5.9) \mathrm{cm}$, body mass $79(11.5) \mathrm{kg}$ ] visited the laboratory on four occasions (two familiarisation and two experimental conditions). In a double-blind, counter-balanced, crossover design participants ingested a placebo [PLA (250 mL sugar free squash)] or tyrosine [TYR (same as PLA plus $150 \mathrm{mg} . \mathrm{kg}$ TYR powder)] $1 \mathrm{~h}$ pre-exercise. Participants completed a 60 min walk at $6.5 \mathrm{~km} \cdot \mathrm{h}^{-1}$, followed by a $2.4 \mathrm{~km}$ time-trial carrying a 25 $\mathrm{kg}$ backpack in $40{ }^{\circ} \mathrm{C}$ and $30 \% \mathrm{rh}$. Aspects of cognitive function were assessed using the PsychE software package, including number vigilance (identification of a duplicate number), dual-task (tracking and stimuli response) and simple reaction time (stimuli response thinking and movement time) at 5 time-points; preingestion, pre-exercise, $30 \mathrm{~min}$ into exercise, post

\footnotetext{
* Correspondence: lee.taylor@beds.ac.uk

Department of Sport Science and Physical Activity (SSPA), University of
} Bedfordshire, Bedford, UK

(c) 2015 Coull et al.; This is an Open Access article distributed under the terms of the Creative Commons Attribution License (http:// creativecommons.org/licenses/by/4.0), which permits unrestricted use, distribution, and reproduction in any medium, provided the original work is properly cited. The Creative Commons Public Domain Dedication waiver (http://creativecommons.org/publicdomain/ zero/1.0/) applies to the data made available in this article, unless otherwise stated.

\section{Discussion}

During TYR and PLA conditions, vigilance, dual task and reaction time cognitive processes declined pre to post exercise. This is surprising since increasing the provision of TYR (a catecholamine precursor), through oral ingestion is suggested to maintain catecholamine synthesis and thus alleviate stress-related decrements in performance; as shown elsewhere during soccer specific exercise [2].

\section{Conclusion}

Ingestion of $150 \mathrm{mg} . \mathrm{kg}$ TYR did not influence cognitive function or any outcome variable associated with steady state exercise or time-trial performance after load carriage $(25 \mathrm{~kg})$ in a hot environment $\left(40{ }^{\circ} \mathrm{C}\right)$.

\section{Published: 14 September 2015}

$60 \mathrm{~min}$ exercise and post time-trial. Measures of heart rate $(\mathrm{HR})$, rating of perceived exertion (RPE), thermal sensation (TSS) and rectal $\left(T_{\text {re }}\right)$ and skin temperature period.

\section{Results}

A significant increase from pre-exercise to post $60 \mathrm{~min}$ task FALSE scores, and for reaction time in both conditions. However, no significant difference was observed tive tests measured $(p>0.05)$. Furthermore, no significant difference was observed in time-trial completion time $\left(F_{1,14}=547.9, p=0.74\right)$ between TYR [19.78(3.44) min] and PLA $[20.29$ (3.55) min]. No significant differperceptual (RPE, TSS) or temperature measures between conditions $(p>0.05)$. 


\section{References}

1. Tumilty L, Davison G, Beckmann M, Thatcher R: Oral tyrosine

supplementation improves exercise capacity in the heat. Eur J Appl

Physiol 2011, 111:2941-2950, doi:10.1007/s00421-011-1921-4.

2. Coully NA, Watkins SL, Aldous JW, Warren LK, Chrismas BC, Dascombe B,

Mauger AR, Abt G, Taylor $L$ : Effect of tyrosine ingestion on cognitive and physical performance utilising an intermittent soccer performance test (iSPT) in a warm environment. Eur J Appl Physiol 2015, 2:373-386,

doi:10.1007/s00421-014-3022-7.

doi:10.1186/2046-7648-4-S1-A148

Cite this article as: Coull et al: Effect of tyrosine ingestion on cognitive function and load carriage performance in the heat. Extreme Physiology \& Medicine 2015 4(Suppl 1):A148.

Submit your next manuscript to BioMed Central and take full advantage of:

- Convenient online submission

- Thorough peer review

- No space constraints or color figure charges

- Immediate publication on acceptance

- Inclusion in PubMed, CAS, Scopus and Google Scholar

- Research which is freely available for redistribution

Submit your manuscript at www.biomedcentral.com/submit
C Biomed Central 